\title{
Weight Classes of Palearctic Bats
}

\author{
Adam KRZANOWSKI
}

\begin{abstract}
Krzanowski A., 1977: Weight classes of Palearctic bats. Acta theriol., 22, 27: $365-370$ [With 1 Fig.].

Forty one bat species occurring in Europe and the Asiatic part of the Soviet Union were studied with regard to their weight classes. The study is based on the literature available. The bats belong to the five weight classes, namely: $2.1-5.0 \mathrm{~g}, 5.1-10.0 \mathrm{~g}, 10.1-20.0 \mathrm{~g}, 20.1-40.0 \mathrm{~g}$, $40.1-80.0 \mathrm{~g}$. The respective species numbers were following: $2(=4.8 \%)$, $18(=43.9 \%), 12(=29.3 \%), 8(=19.5 \%), 1(=2.4 \%)$. The modular weight class is in the $5.1-10.0$-gram weight class. The curve of the weight distribution is highly skewed towards small weights. The lowest weight class is very poor in species. Summarizing, the rules of body weight distribution of insectivorous bats have been confirmed for the Palearctic species.

[Inst. Syst. Exp. Zool., Polish Acad. Sci., Sławkowska 17, 31-016 Kraków, Poland]
\end{abstract}

\section{INTRODUCTION}

The studies of the weight classes in bats have begun only recently. Here the names of $\mathrm{Mc} \mathrm{Nab}(1969,1971), \mathrm{B} \mathrm{lack}(1974)$, and $\mathrm{F}$ e $\mathrm{n} \mathrm{ton}$ (1975) can be mentioned. The interesting results of these studies are that - as far as the insectivorous bats are concerned - in all three north temperate bat faunas (New Mexico, Wisconsin, and Arizona) as well as in several tropical bat faunas (Tamaulipas, Veracruz, Suriname, Trinidad and small Caribbean islands) the modular weight class was $5.1-10.0$ grams, and the respective distributions were highly skewed towards small weights. Further, the percentage of bats in the smallest weight class was distinctly higher for the tropical bats.

These results are in accordance with an ecological model of size distribution in animals as proposed by $\mathrm{Hutchinson} \& \mathrm{MacArthur}$ (1959).

In order to check the above rules in other regions of the world I took into consideration the Palearctic.

\section{MATERIAL AND METHOD}

The present study is based entirely on the literature and is limited to Europe and the Asiatic part of the Soviet Union. The bats are insectivorous. In cases 
when the weights were lacking I classified the corresponding species on the basis of their external measurements: namely, I compared them with related species in which both the external measurements and the weight were known.

\section{RESULTS}

The study comprises 41 species, of which 34 belong to Vespertilionidae, 6 to Rhinolophidae, and 1 to Molossidae. Their distribution into the weight classes is following:

1) $2.1-5.0$ grams. Myotis muricola, Pipistrellus pipistrellus. In all, two species which make $4.8 \%$.

2) 5.1-10.0 g: Rhinolophus hipposideros, Myotis bechsteini, M. daubentoni, $M$. nattereri, $M$. emarginatus, $M$. mystacinus, $M$. brandtii, $M$. frater, Plecotus auritus, P. austriacus, Barbastella barbastellus, Pipistrellus nathusii, P. abramus, P. kuhli, P. savii, Eptesicus bobrinskii, Murina leucogaster, M. aurata. In all, 18 species, which make $43.9 \%$.

3) 10.1-20.0 g: Rhinolophus euryale, Rh. blasii, Rh. mehelyi, Rh. bocharicus, Myotis dasycneme, M. capaccinii, Miniopterus schreibersii, Barbastella leucomelas, Nyctalus leisleri, Eptesicus nilssoni, E. bottae, Vespertilio murinus. In all, 12 species, which make $29.3 \%$.

4) 20.1-40.0 g: Rhinolophus ferrumequinum, Myotis blythi, M. myotis, Nyctalus noctula, Vespertilio superans, Eptesicus serotinus, Otonycteris hemprichi, Tadarida teniotis. In all, 8 species, which make $19.5 \%$.

5) 40.1-80.0 g: Nyctalus lasiopterus. One species, which makes $2.4 \%$.

Remarks: $M$. muricola (=ikonnikovi): according to $\mathrm{H}$ a nák (1965) this species in confined to eastern Asia and its occurrence in Europe has not been proved. I assigned it to the lowest weight class because it is smaller than M. mystacinus. Its direct weight measurements seem to lack.

$P$. pipistrellus: its assignment to the lowest weight class has been somewhat arbitrary because the corresponding data are conflicting (R y berg, 1947; K ö n i g, 1969; Strelkov, 1963; A belentsev et al., 1956; Hůrka, 1973; Mayer \& Wirth, 1971; Haensel, 1967; S t ebbings, 1966, 1968; Lovet t, 1961).

M. mystacinus: I assigned it not without hesitation to the $5.1-10.0 \mathrm{~g}$ class, mainly on the basis of data supplied by $\mathrm{H}$ a ná $\mathrm{k}$ (l.c.), H ůrka (l.c.), and Stre l$\mathrm{kov}$ (personal communication) although other indications assign it to the lowest weight class (R üssel \& Wilhelm, 1971; Ma yer \& Wirth, l.c.; Gauckler \& Kra u s, 1970). Data given by Moš a nský \& G a i s ler (1965) are inconclusive.

$M$. brandtii: weight data for this species have been found in $\mathrm{Hanák}$ (l.c.), R üs sel \& Wilhelm (l.c.), Hůrka (l.c.), May er \& Wirth (l.c.), Ga uckler \& $\mathrm{Kraus}$ (l.c.), and Strelkov (1971 and personal communication).

M. frater (= longicaudatus): its external measurements (Strelkov, 1963) are comparable with those of $M$. bechsteini. Direct weight measurements are lacking.

$P$. abramus: its weight data seem to be lacking. Its external dimensions are similar to those of $P$. kuhli and $P$. savii, which qualifies it to the same weight class.

E. bobrinskii: 7 not gravid females weighed in May-June $5.8-8.3 \mathrm{~g}$, mean was 
$7.0 \mathrm{~g}$. 4 males weighed in the same months $6.5-9.0 \mathrm{~g}$, mean being $7.85 \mathrm{~g}$ ( $\mathrm{S}$ tr e l$\mathrm{k}$ ov, personal communication).

$M$. leucogaster (=hilgendorfi): the weight measurements of this species are unknown to me. Its external measurements (Strelkov, 1963) are not unlike those of $B$. barbastellus, therefore it seems to belong to the 2nd weight class, but the 3 rd class can not be excluded.

M. aurata (= ussuriensis): the only known weight measurement amounts to $6.3 \mathrm{~g}$, it was a male (Strelkov, personal communication). However, this specimen was perhaps very fat, as according to $\mathrm{W}$ allin (1969) it is a tiny species. Therefore it may be assigned to the lowest weight class as well.

$R h$. blasii: the data on its weight are quite scanty. 23 males weighed in June 9.0-11.0 g, mean $9.91 \mathrm{~g}$ (Van L a a \& D a an, 1964). S trelkov (personal communication) gives the weight of 5 females as $9.6-10.6 \mathrm{~g}$, mean $10.02 \mathrm{~g} ; 3$ males weighed 9.2-10.0, mean $9.6 \mathrm{~g}$. Strelkov weighed these bats in summer, when they are rather meager. Concerning the data supplied by Van La a r \& Da a n (l.c.) it must be remarked that females in Rhinolophidae, at least in Rh. ferrumequinum and Rh. hipposideros (V e s e y-Fitzger a ld, 1949) are bigger than males. Moreover, the external dimensions of $R h$. blasii are quite similar to those of $R h$. euryale. Therefore I assigned it to the $3 \mathrm{rd}$ weight class.

Rh. blasii: the data on its weight are quite scanty. 23 males weighed in June $R h$. ferrumequinum which only slightly exceeds $20.1 \mathrm{~g}$. Therefore its assignment to the 3rd weight class seems to be justified.

Rh. bocharicus: $\mathrm{Strelkov}$ (1963) gives its weight as $8.3-20.6 \mathrm{~g}$.

M. capaccinii: according to $\mathrm{K}$ ö $\mathrm{nig}$ (l.c.) its weight is $8-15 \mathrm{~g}$.

M. schreibersi: only $\mathrm{König} \mathrm{(l.c.)} \mathrm{gives} \mathrm{its} \mathrm{weight} \mathrm{as} 8-11 \mathrm{~g}$. Other authors (Van den Brink, 1972; Dumitrescu, Tanasachi \& Orghidan, 1955; Mirić, 1960) give higher values which qualify it to the 3rd weight class.

B. leucomelas (= darjelingensis): $\mathrm{Strelkov}$ (1963) gives its weight as 8-18 $\mathrm{g}$.

E. bottae (=ognevi, see Hanák \& Gaisler, 1971): according to $\mathrm{S}$ trelkov (1963) its weight is $8-20 \mathrm{~g}$.

M. blythi (=oxygnathus): its weight is given by Strelkov (1963) as $15-30 \mathrm{~g}$.

$V$. superans: the direct weight measurements are lacking. The external dimensions are comparable to those of $E$. serotinus and therefore it has been qualified to the same weight class.

O. hemprichi: $17-30 \mathrm{~g}$ (S t r elk ov, 1963).

N. lasiopterus: $41-76 \mathrm{~g}$ (S t r el k ov, 1963).

The above results are shown graphically in Fig. 1.

\section{DISCUSSION}

As can be seen from the great geographical area covered by the present paper the principle posed by $\mathrm{Hutchins}$ on \& M a c A r thur (i. c.), namely excluding allopatric species has not been followed. However, in some other areas studied (e.g. Arizona) the above principle has not been followed, either.

The individual and geographical variability, the sex dimorphism as well as physiological state can greatly influence the weight. E.g. the bats living on islands are often smaller than the same species from continent 
(K rzanowski, 1967), the Bergmann's rule may play some role, in most Vespertilionids the females are somewhat bigger than males, the bats attain their highest weight at the beginning of hibernation (B e e r \& Richards, 1956; Krzanowski, 1961), the influence of gravidity and that of empty or full stomach is a matter-of-course. The physiological condition of a bat is often not recorded in the sources concerning weight. However, if one uses several sources and, if these sources are in turn the compilations of many other ones, such randomness can be avoided to a satisfactory degree. I suppose that the bats handled in the present paper have found their way to the proper weight classes in the overwhelming majority of cases and, that the few possible errors do not change the overall picture of weight distribution. This distribution is quite in accordance with the results of other papers mentioned in Introduction, namely the curve (Fig. 1) is strongly assymetrical, with its left

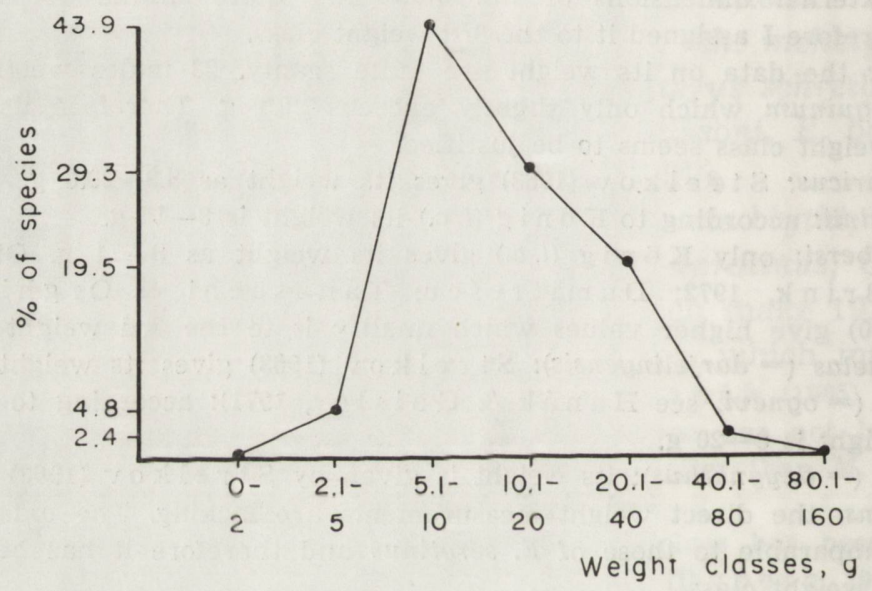

Fig. 1. Frequency distribution of body weights for Palearctic bat fauna.

part being short and steep while its right part is long and slants gradually. The species scarcity in the lowest weight class is characteristic for the temperate bat faunas, too. As in the case with other bat faunas the modular weight class is $5.1-10.0$ g. B lack (l.c.) hypothesizes the abundance of species in this weight class to be a reflection of the abundance of insects in the 6 to 10 -millimeter length class. Here the paper by Fenton (l.c.) seems to pose an exception: the author found the modal value for the Rhodesian insectivorous bats to be $10.1-20.0 \mathrm{~g}$ (p. 14.).

Probably no temperature zone bat belongs to a higher weight class than $40.1-80.0 \mathrm{~g}$. 


\section{REFERENCES}

1. Abelentsev V. I., Pidoplichko I. G. \& Popov B. M., 1956: Fauna Ukraini, 1, Ssavtsi, No. 1: 1-448. AN URSR, Kiiv.

2. Beer J. R. \& Richards A. G., 1956: Hibernation of the big brown bat. J. Mamm., 37, 1: 31-34.

3. Black H. L., 1974: A north temperate bat community: structure and prey populations. Ib., 55, 1: 138-157.

4. Dumitrescu M., Tanasachi J. \& Orghidan T., 1955: Contribution à l'étude de la biologie des Chiroptères: dynamique et hibernation des chiroptères de la caverne aux chauves-souris du Monastère de Bistrita. Bul. stiint. Acad. R.P. Romine, sec. biol., 7: 317-357.

5. Fenton M. B., 1975: Observations on the biology of some Rhodesian bats, including a key to the Chiroptera of Rhodesia. Life Sci. Contrib., R. Ontario Mus., 104: 1-27.

6. Gauckler A. \& $\mathrm{Kraus}$ M., 1970: Characteristics and distribution of Myotis brandti (Eversma n, 1845). Z. Säugetierkde., 35, 2: 113-124.

7. H a en sel J., 1967: Notizen über 1963-1966 insbesondere in Berlin aufgefundene Fledermäuse. Milu, 2: 313-322.

8. Hanák V., 1965: Zur Systematik der Bartfledermaus Myotis mystacinus $\mathrm{Kuhl}, 1319$ und über das Vorkommen von Myotis ikonnikovi Ognev, 1912 in Europa. Acta Societ. Zool. Bohemoslov., 29, 4: 353-367.

9. Hanák V. \& Gaisler J., 1971: The status of Eptesicus ognevi Bobrin$\mathrm{ski}, 1918$, and remarks on some other species of this genus (Mammalia: Chiroptera). Ib., 35, 1: 11-24.

10. H ůrka, L., 1973: Ergebnisse der Fledermausberingung in Westböhmen in Jahren 1959-1972 mit Bemerkungen zum Vorkommen, Ökologie und Ektoparasiten der Fledermäuse. Sbornik Zapadoceske Muz. Plzni, 9: 1-84.

11. Hutchinson G. E. \& M a c Arthur R. H., 1959: A theoretical ecological model of size distributions among species of animals. Amer. Natur., 93, 869: $117-125$.

12. König C., 1969: Wildlebende Säugetiere Europas. Chr. Belser Verlag: 1-256. Stuttgart.

13. Krzanowski A., 1961: Weight dynamics of bats wintering in the cave at Puławy, Poland. Acta theriol., 4, 13: 249-264.

14. Krzanowski A., 1967: The magnitude of islands and the size of bats (Chiroptera). Acta zool. cracov., 12, 11: 281-348.

15. Lovett W. V., 1961: A feeding population of pipistrelle bats (P. pipistrellus). Trans. Suffolk Nat. Soc., 12: 39-43.

16. Mayer A. \& Wirth J., 1971: Die Fledermäuse Österreichs. 1-32, Landesverein für Höhlenkunde in Wien und Osterreich. Wien.

17. M c N a b B. K., 1969: The economics of temperature regulation in Neotropical bats. Comp. Biochem. Physiol., 31: 227-268.

18. M c N a b B. K., 1971: The structure of tropical bat faunas. Ecology, 52, 2: 2: $352-358$.

19. Miri ć D., 1960: Slepi misevi (Chiroptera) Petrovaradinske tyrdave. Bull. Mus. Hist. Nat. Belgrade, ser. B, 16: 135-171.

20. Mošanský A. \& Gaisler J., 1965: Ein Beitrag zur Erforschung der Chiropterenfauna der Hohen Tatra. Bonn. Zool. Beitr., 16, 3-4: 249-267. 
21. R üs el F. \& Wilh elm M., 1971: Die Grosse Bartfledermaus (Myotis brandti Eversmann 1845) im Osterzgebirge gefunden. Nyctalus, 3: 64a.

22. Ryberg O., 1947: Studies on bats and bat parasites. 1-330. Bokförlaget Svensk Natur Stockholm.

23. St e b bing s R. E., 1966: Bats associated with a Plecotus colony. J. Zool., 150: $492-493$.

24. S t e b b ing s R. E., 1968: Measurements, composition and behaviour of a large colony of the bat Pipistrellus pipistrellus. J. Zool., 156: 15-33.

25. Strelkov P. P., 1963: Chiroptera - Rukokrylye. [In: "Mlekopitajuščie fauny SSSR «, Ed. Sokolov I. I.], 1: 122-218. AN SSSR, Moskva - Leningrad.

26. Strelkov P. P., 1971: Ekologičeskie nabludenia za zimnei spjačkoj letučih myšej (Chiroptera, Vespertilionidae) Leningradskoi oblasti. Tr. zool. Inst., 48: $251-303$.

27. Van den Brink F. H., 1972: Die Säugetiere Europas. Paul Parey: 1-217. Hamburg und Berlin.

28. Van La a r V. \& Da n S., 1964: On some Chiroptera of Greece. Beaufortia, 10, 120: $158-166$.

29. Vesey-Fitzgerald B., 1949: British bats. Methuen: $1-60$. London.

30. Wallin L., 1969: The Japanese bat fauna. Zool. Bidrag Fran Uppsala, 37, 3-4: $223-440$.

Accepted, December 16, 1976.

\section{Adam KRZANOWSKI}

\section{STRUKTURA CIĘŻAROWA NIETOPERZY PALEARKTYKI}

\section{Streszczenie}

Celem pracy było stwierdzenie ilości gatunków nietoperzy Europy i Związku Radzieckiego w poszczególnych klasach ciężarów ustanowionych dla nich przez badaczy, a mianowicie: $2,1-5,0 \mathrm{~g}, 5,1-10,0 \mathrm{~g}, 10,1-20,0 \mathrm{~g}, 20,1-40,0$ g $40,1-80,0 \mathrm{~g}$. Badania objęły 41 gatunków (34 - Vespertilionidae, 6 - Rhinolophidae, 1 Molossidae). Oparto je wyłącznie na literaturze; w braku danych wnioskowano o ciężarze przez porównywanie wymiarów zewnętrznych z odpowiednimi wymiarami gatunków o znanym ciężarze. Rozkład gatunków w powyższych 5 klasach ciężarów był następujący: $2(=4,8 \%), 18(=43,9 \%), 12(=29,3 \%), \quad 8(=19,5 \%)$, $1(=2,4 \%$ ) (Ryc. 1). Wyniki powyższe zgodne są z regułą znalezioną dla nietoperzy innych krajow (w Stanach Zjednoczonych - New Mexico, Wisconsin i Arizona, w Meksyku - Tamaulipas i Veracruz, poza tym Surynam, Trynidad i małe wyspy na M. Karaibskim). Wg tej reguły struktura ciężarowa daje się przedstawić w postaci silnie asymetrycznej krzywej, której lewe ramię jest strome i krótkie, prawe zaś znacznie dłuższe i opada łagodnie. Nietoperze klimatu umiarkowanego wykazują znaczne procentowe zmniejszenie ilości gatunków w klasie ciężarów najniższych a procentowo najwięcej gatunków występuje zawsze w klasie 5,1-10,0 g. 